\title{
The Epidemic Disease Act 1897 and its Amendment - A Perspective
}

\author{
Padma Kumar K \\ Professor \& Head, Forensic Medicine \& Toxicology, Jubilee Mission Medical College \& Research Institute, Thrissur, Kerala-680005.
}

\begin{abstract}
The Epidemic Disease Act was enacted in 1897 to stop the spread of bubonic plague outbreak in Bombay at that time. The Act gives powers to the central and state government to take special measures and prescribe regulations to prevent the spread of dangerous epidemic disease. The act was invoked many times in the country since then and the last was in 2018 to prevent the spread of cholera in a Gujarat village. The covid-19 pandemic made the country to a standstill and the government machinery, health care workers and officials are working day night to contain the virus. The most unfortunate thing that happened in our country is unprovoked abuse, harassment and violence on the people who are at the forefront to implement preventive strategies by the public. The government felt that The Epidemic Disease Act was insufficient to protect the workforce and a new ordinance was brought to amend the Epidemic Disease Act of 1897. The ordinance has introduced a bill in both sections of parliament and now became an act. Both the act and its amendment are discussed here.
\end{abstract}

Keywords: Covid pandemic, Epidemic disease, Health care personal, The act of violence.

Int J Eth Trauma Victimology (2021). DOI: 10.18099/ijetv.v7i01.7

\section{INTRODUCTION}

$\mathrm{T}$ he Epidemic Diseases Act, 1897 is an act promulgated by former British India Government in Mumbai to deal with bubonic plague during that time. ${ }^{1,2}$ The act was introduced to control the epidemic by providing special powers to authority to implement containment measures and thus preventing the spread of the disease. The main purpose of this act was to empower State and Central governments for the prevention and spread of any epidemic disease.

The 123 years old Act empowers the state governments to take special measures and prescribe regulations in an epidemic. It defines penalties for disobedience of these regulations. The Act also protects a person acting in good faith from any legal proceeding arising out of his actions as per the provisions of the act. The most recent use of the act was in Maharashtra in 2009 during the outbreak of ${ }^{3} \mathrm{H} 1 \mathrm{~N} 1$ influenza and also in Gujarat in 2018 during Cholera outbreak. ${ }^{4}$ The act again became relevant during the year 2020 .

Health care workers involved in COVID-19 related curative and preventive measures are being attacked in various countries and the situation is pretty bad in our country. They are subjected to abuse and violence while they are involved in their work to contain the virus. This especially happens when they trace out the cases and contacts in the community. There are many reports from various parts of the country that the health care workers are subjected to unprovoked violence from the common people. The Government of India wanted to curb this menace of humiliation and attack on health care workers and officials who are in the forefront of pandemic prevention. With this aim, President of India promulgated the Epidemic Diseases Amendment Ordinance $2020^{5}$ to amend the Epidemic Diseases Act, 1897 on April 22, 2020. Later during
Corresponding Author: Dr. Padma Kumar K, Professor \& Head, Forensic Medicine \& Toxicology, Jubilee Mission Medical College \& Research Institute, Thrissur, Kerala-680005., e-mail: drpkfmt@ gmail.com

How to cite this article: Padma K.K. The Epidemic Disease Act 1897 and its Amendment - A Perspective. Int J Eth Trauma Victimology. 2021;7(1):35-36.

Source of support: Nil

Conflict of interest: None

Received: 14/05/2021;

Accepted:03/06/2021;

Received in revised form: 22/05/2021; Published: 25/06/2021

September 2020, the ordinance has introduced a bill in both houses of parliament and passed. The various provisions of this amendment and existing provisions of the epidemic disease act are discussed below.

\section{Health Care Service Personal, Property and act of Violence}

A new section has been inserted which defines a health care service personal, property and act of violence in the context of an epidemic disease.

Health care service personal includes a doctor, nurse, paramedical worker and community health worker. Any person to whom a power is given to take measures for preventing the outbreak and spread of disease also included in the ambit of health care service personal. A clinical establishment, a mobile medical unit, any facility for quarantine and isolation of patients during an epidemic are included as property as per the ordinance.

Act of violence includes: (i) Causing hindrance to a duty of health care service personal, (ii) Preventing a health care 
service personal from doing his work, (iii) Harassment which has an impact on the living and working condition of health care service personal, (iv) harm, injury, hurt, intimidation or danger to the life of health care service personal and (v) loss or damage to property or documents in the custody of health care service personal.

\section{Travel and Segregation}

The original act gives power to the state government for inspection of travelling persons and segregation of them if suspected. A government can detain such a person intending to sail or arriving in the country.

There was a section in the Epidemic Disease Act of 1897 which gives power to the central government for taking measures to inspect ship or vessel arriving or leaving at any port. It looks ironic in this modern era where the modes of conveyance are many. The amendment added bus or train or goods vehicle or aircraft leaving or arriving at any land or port or aerodrome in addition to ship or vessel.

\section{Penalty existed Before Amendment Ordinance}

The persons disobeying the regulations of provisions of the act is punishable under section 188 of the Indian Penal Code. This is the only penalty incorporated in the Epidemic Disease Act 1897. Disobedience to the provisions of the act attracts simple imprisonment up to one month or a fine of up to two hundred rupees or both. If the disobedience causes danger to human life, health or safety, the punishment is imprisonment up to six months or a fine of up to a thousand rupees or both. More aggressive punishments are incorporated in the new ordinance in addition to this section.

\section{Penalty Inserted by Amendment Ordinance}

Any act of violence against a health care personal and causing damage to the property is punishable with imprisonment and a fine. The minimum imprisonment is three months and this can be up to five years. The fine is fifty thousand rupees to two lakhs rupees. The victim can enter into a compromise and can drop the case against the accused.

If the act of violence causes grievous hurt to the health care personal the punishment is more. The minimum imprisonment is six months and this can be up to seven years and with a fine. The fine is one lakh rupees to five lakhs rupees. The victim cannot enter into a compromise.
Both of the above are non bailable offences too. In addition to the punishment, the court can determine compensation also for the hurt that occurred to the health care personal. In case of damage to property, the court can decide compensation also. The compensation payable is twice the amount of market value of the damaged property. In the case of non-payment of compensation, there are provisions for recovery from land revenue.

The amendment makes it clear that the investigation must be completed within a period of thirty days from the date of registration of the first Information report and the trial within a period of one year.

\section{Conclusion}

The Epidemic Disease act 1897 gives authority for the state government to take special powers and prescribe regulations when a dangerous epidemic disease occurs. But the law does not define an epidemic disease and when it becomes dangerous. The amendment brought in mainly to prohibit violence against health care workers and damage to property in which health care workers have a direct relation to the epidemic. Both the original act and the amendment are into administrative dealing of dangerous epidemic disease and not into any scientific aspect. The respective departments and authorities are coming out with scientific regulations as and when required depending on the warrant of current situations. When a global pandemic occurs, the most ideal is thave a common law for the whole country with administrative dealing and scientific efforts.

\section{REFERENCE}

1. The Epidemic Disease Act of 1897. Act No 3 of 1897

2. Arnold D. Science, technology and medicine in colonial India. United Kingdom: Cambridge University Press; 2000: p143.

3. Epidemic Diseases Act: What it means' Economic Times, August 05, 2009, available at https://economictimes.indiatimes.com/ epidemic-diseases-act-what-it means / article show $/ 4859450 . \mathrm{cms}$ ? From $=\mathrm{mdr}$, accessed on August 25, 2020 at 01 p.m

4. A 123-year-old law, once used to imprison freedom fighters, is India's primary weapon against coronavirus' QZ, March 23, 2020, available at https:/qz.com/india/1820143/india-battlescoronavirus-with-british-era-epidemic-diseases-act/, accessed on August 28, 2020 at 01.30 p.m.

5. Ministry of law and justice, The Epidemic Disease (Amendment) Bill 2020 